\title{
Music as Edae: The Implications for Music Therapy in Nigeria
}

\author{
Charles O. Aluede*
}

\section{Abstract}

The use of music under social, political, moral, and religious circumstances in Africa is evidenced not just by the quality and quantity of the work done in this area of scholarship but, by the corpus of traditional songs whose texts, when critically examined lead us to important conclusions in forming opinions of their utility. This work examines the use of music in the restoration of good health. In the course of investigation, field work which involves participant observation, library search for relevant literature, interviews and chance talks were employed in eliciting germane information. Interestingly, this paper observes that there is a disconnect between the old use of music in Nigerian societies and its present use. It remarks that this disconnect is possibly the bane of the myriads of general ill health often experienced by man in contemporary Nigerian societies. It was suggested that if music is to uplift and heal man, then it should be culturally relevant, performed communally, the repertoire carefully selected to suit the target group and above all, have a determined duration of performance within a cultural context.

http://dx.doi.org/10.4314/ujah.v13i1.5

Key words: prophylactic treatment, allopathic therapy, illhealth and wellbeing

\section{Introduction}

Health as exemplified in the prevention and treatment of illness ranks highest in the agenda and financial budgets of most nations of the world including Nigeria. The various ethnic groups, which make up Nigeria, are not left out in this chase of good health. However, it could be observed that 
against their primordial beliefs of disease causation, vigorous attempts are often made and directed towards the importation of drugs, vaccines and bio - medical laboratory equipment in the service of the citizenry. Inasmuch as this stride is highly commendable, one may wonder how far this chase of good health has gone and how far it can get to. Several efforts are being made around the world to cure these diseases and to bring them under control (Navneet, 2002). This has resulted in various kinds of therapeutic systems, out of which the most basic is allopathic therapy. Allopathic therapy has to do with the use of drugs in the treatment of ailments. These drugs could be administered orally or in intra muscular or intraveinous forms. It has been noted also that these drugs when administered have their own side effects. The use of music in healing does not have any side effects and so its use has to be strengthened. Cottrell (2002) confirms "Since the beginning of recorded history, music has played a significant role in the healing of humankind; music and healing were communal activities which were natural to everyone" (p.15).

It is obvious that the mind has great influence over the body especially in psychosomatic cases. While it is not being suggested here that the use of drugs should be discontinued or that the efficacy of such drugs are under query, it is however the position of the author that we gradually work towards an integrative bio-medical practice in Nigeria because if the culture of the client is not understood by the therapist, any therapeutic intervention may not achieve much in bringing about healing.

It has been observed that music contributes to the psychological, emotional, social, educational and health needs of man. In what follows, this paper discusses the use of music in traditional healing in Nigeria. 


\section{What is Edae?}

Edae or Edai $^{1}$ is an Esan vocabulary. Esan is a language spoken by a group of people and also a name of a land mass and its inhabitants in Edo central senatorial district of Edo State Nigeria. Below is a map of Nigeria showing Edo State to which the Esan people belong.

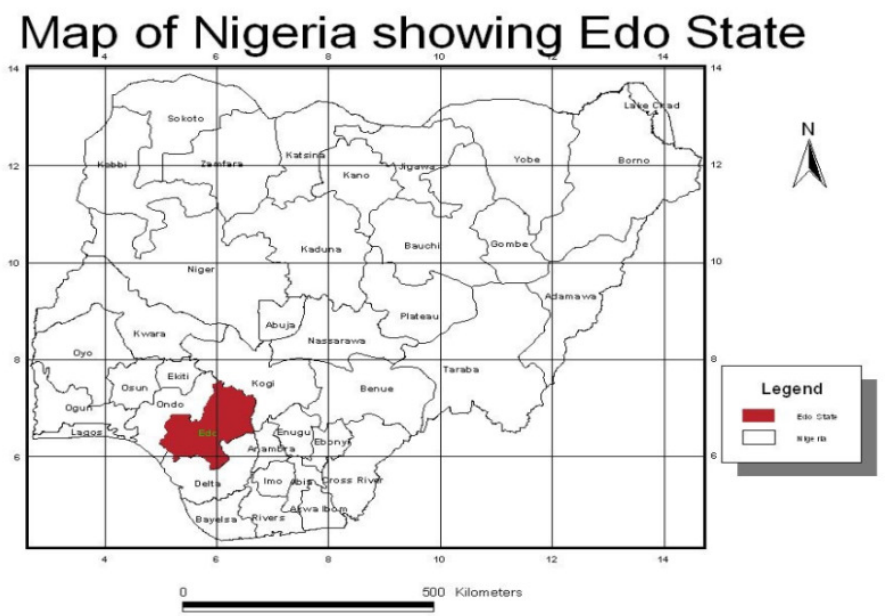

Edae is an Esan term for an amulet or potion, which is either worn on the neck, waist, hand or hung on a tree or on roof top to elongate the life span of its user provided it is secured and applied as directed. It is also believed that on being loosened from the user's neck, removed from the roof top or tree top and brought in contact with the ground the user dies when a ripe old age has been attained. In another parlance Edae could be administered to women with records of incessant abortion at their early stages of pregnancy, Okogie (1994) remarked that:

At about the third month of pregnancy, a native doctor (traditional healer) makes an anti abortion string which is worn round her waist more rarely round her neck. Whatever happened, the string was never allowed to fall to the ground, for the day she did that, the foetus would drop before the woman would go into normal labour ( p.155). Viewed from 
any perspective, Edae is seen as that which preserves, conserves and safeguards.

\section{What Relevance Has Edae with Music?}

In the preceding paragraph, it was established that Edae has powers to elongate life span. In most African societies, leaving to an old age is seen as God's favour which everyone prays for. Although life is a preparation for death (Bhaktipada, 1988) he opines further that "death is like an arrow that is already in flight, and your life lasts only until it reaches you" (p.49).So death hovers around every mortal but by one's careful habits, discipline, religious observances of age old truths and caution in daily living, one can live a long and healthy life. Music though not charm, talisman or amulet has been observed to share the attributes of Edae in calming someone, diverting ones thought from a glooming to gay one and strengthening a weak mind to heal the body.

Music is often said to be a diversionary tool because it makes the mind to rise above the challenges that would have weighed the body down. On the link between the mind and the body, Siegel (1986) remarks:

The state of the mind changes the state of the body by working through the central nervous system. Peace of mind sends the body a "live" message, while depression, fear and unresolved conflict give it a "die" message. Thus all healing is scientific, even if science cannot yet explain exactly how the unexpected "miracle" happens (p.3).

Without doubt, a depressed fellow can go into some forms of anti-social conducts such as drunkenness, poor health habits and even commit suicide. Such acts could abbreviate individual's life span. Conversely, a calm mind reduces one's 
susceptibility to disease and illness. Ganesan (2006) maintains that "pure air and water, a nutritious diet, are all necessary to keep the body healthy, if mental health is not maintained, the nervous system is thrown out of gear disturbing normal functioning of the body" (p.93). In the present day medical practice, exercise is constantly mentioned to be good for the heart. While it is not easy to religiously keep to a fixed time table for 'exercises for exercises' sake, music in Nigeria being an eclectic art form is replete with polyrhythm and highly intertwined with dance. Music making in sub-Saharan Africa is a form of exercise in that musical activities go with dance, drumming, hand clapping or other forms of instrumentation. In all, it will be superfluous to further mention that all these are physically challenging. Music as a collective human activity in Nigeria is known to be commonly combined with dance whether under the entertainment, religious or ritual situation. Dance is a strong concomitant with music.

It is therefore evident that the mind has so much influence on the well-being of humans. The Holy Bible in the book of Proverbs chapter 17 verse 22 says that: "A cheerful heart is good medicine, but a crushed spirit dries up the bones" One may ask: What makes a cheerful heart? The answer is music of good tidings, good instrumental accompaniment and culturally accepted sound. Music, which is often regarded as the food of the soul makes a cheerful heart. What makes a crushed spirit? - Anger, grief, pain, sickness and unresolved crises. What is the biblical significance of bones as used in this context? The bones as used in this context mean the mortal bodies. From the foregoing, we hereby propose this equation: music + mind + body $=$ physical wellness. Can this opinion be real or is it illusionary? If true for how long will it take for music to induce healing? These and indeed other questions are the thrust of the discussions below. 


\section{How Can Music Be Employed as Edae?}

Earlier in this paper, Edae was discussed as a bodily attachment which elongates one's life span. To employ music as Edae in the context of this discourse is not to attach musical instruments to ones body but to intentionally and periodically bathe one's self in music as a preventive measure against illhealth. Down through the ages, every civilization on our planet has taught that one can use the human voice for self healing. China, India, Egypt, Greece, Rome, Africa, America, all had civilizations that used chanting, toning, singing, loving speech, for self healing. All music was live, and vocal music was the most alive of all (Timothy,1999).

He further observes:

Chanting is done worldwide and has been going on for centuries. The majority of 5 billion people on the earth today do some form of chanting on a regular basis. Chant groups travel around India, chanting as a group wherever they go. Now that is a kind of group activity that does not end up in a jail cell. Chant choirs have existed in India, China, Africa, and even the chant choirs of Catholic Church. Most of the time, chanting was seen and performed as a spiritual activity. Not just for self healing, but to heal entire nations, and to keep the planet whole (p.2).

From empirical and analytical study of music in therapy or music as therapy, it has been noted that music has so much influence on healthfulness. In his bid to investigate a strange illness that had come over a Benedictine Monastery in the South of France whereby seventy out of ninety monks became depressed, lethargic, fatigued and unable to perform their daily tasks, the French surgeon, Alfred Tomatis, noted that their new 
Abbot had drastically reduced their chants like "Gloria in Excelsis Dei" and when this chanting stopped, they became tired and depressed and as soon as they returned to the old order of chanting between eight and nine times a day for about twenty minutes each, dramatic changes occurred because the monks' health was restored (Corttrell,2000). Siegel (1986) talking about the time patients die in hospitals, he said: "the vast majorities die in the early morning when the lifesavers are resting and the family guide has left or fallen asleep. Then there is no interference or guilt over, leaving" (p.206) the immediate excerpt above has identified two major issues and they are: That a vast majority of patients die during the early hours of the morning and that death occurs when one's environment is quiet and devoid of any ambient sound or interference. Aluede (2006), corroborates the above observation in this statement:

In African societies, there are many pointers which indicate their firm belief and practice of music therapy. A major one of such is that music can be used to revive a dying person or animal. In African states, there is the notion that a dying person needs absolute silence (perfectly peaceful atmosphere to expire... To resuscitate a dying person, a single tone of wind instrument is sounded into the person's ear. For little chicks and other birds, a bowl is turned upside down encircling the animal while a healing song with intense drumming on the bowl is carried out. This practice has quite often yielded results (p.33).

Siegel (1989), Tomatis (2005) and Aluede (2006) made some startling revelations that: the absence of music in one's life, could make individuals susceptible to illness, the presence of 
music in one's life could be a form of prophylactic treatment and that music has the propensity to restore to good health a sick folk. It could therefore be concluded that music as seen from the relevant literature in this paper has healing attributes. However, the changing life styles of Nigerians have left them without time to listen to music of one's choice but to be caught up as a captive audience in offices, bus stops, banks, radio stations and roadside hawkers of CDs. These products and avenues of musical performances are far from what it was or should be. In these cases, the listeners are left with no choice but to be bathed in musical genres which they have no control over. By this we mean that the listener is held captive for as long as his transactions last in such places without being able to make a choice of what he wants to hear not even to talk of adjusting the volume of the music. In spite of the healing attributes of music, Mackenzie (1988) says:

Music does influence the listeners, even if one is not aware of it consciously; the body is constantly reacting to the sound. Variations in pitch, rhythmic patterns, tempo and volume will affect pulse rate, blood pressure, respiration and the function of certain glands. These in turn will create a mood or physical response. Some music can make you relax... (p. 45).

From Mackenzie's remark music has great therapeutic potentials irrespective of our awareness. For example studies in physiological response to music support the hypothesis that listening to music influences a person's autonomic responses. Music played at a higher register increases tension and that on a lower one decreases tension. Music that is played at 80-90 beats per minute increases tension while that played at 40-60 beats per minute decreases tension Cottrell (p.5). Although Cottrell's idea of frequency of beats may not have the same 
influence on people of different races irrespective of geographical location and culture, it attests to the fact that music in itself has serious influence on mortals.

\section{How Music as Edae Was Organized in Nigeria}

Long before the $19^{\text {th }}$ century, music making was a communal activity in the Nigerian society, and the avenues for musical performances were collectively determined. Beyond the very well publicized functions of African music, music also functions during the mourning periods of one's spouse, siblings and parents and during the cleansing of the land (this could mean town or village or community). During moon-lit nights people of the same age grades put themselves into groups to sing and dance together. It is also at such times that people of the different age grades gather around their aged parents and grand parents to be told stories with musical prelude, interlude and postludes. Beyond the above stated avenues, music making is also concomitant with the construction or reconstruction of neighbours' houses or destroyed houses, and when a neighbour is under the grip of illness.

From the above, one can discern that music helps to strengthen individuals in times of bereavement, to cleanse the land, to create an opportunity for social interaction, to educate and rehabilitate, to create room for exercise and movement skills during music and dance, to stabilize the emotions of community dwellers. Through group musical activities, a sort of conscious or unconscious prophylactic treatment for participants are provided to ease the tension of the day's challenges and more importantly to heal the sick among them. The energy and rhythm of most Nigerian songs are characteristic of African music, which is usually polyrhythmic and dance knitted. In trying to dance to such music, rigorous dance steps are employed and in doing this, the body is 
exercised. Mereni (1997) identified five kinds of music therapy thus:

i. Anxiolytic music therapy - aims to free one from fear, fright or anxiety.

ii. Tensionlytic music therapy - aims to relieve one from physical and mental tension resulting from manual or spiritual labour.

iii. Algolytic music therapy - aims to relieve physical pain.

iv. Psycholytic music therapy - aims to loosen a person from the group of evil spirits.

v. Patholytic music therapy - aims to relieve the grief of bereavement.

An examination of the six highlighted uses of music shows that it falls under the different shades of music therapy which Mereni has identified. In the instances mentioned above, whether music is to release tension, relieve pain, free one from the grip of fear or relieve the grief of bereavement, music is made as a collective human activity. Singing, clapping, drumming or combining any two musical activities improve the cognitive potential of the participants. These are in themselves strands of group music therapy. For example among the Esan of Edo State and the Orogun- Urhobo of Delta State Nigeria, in times of grief, they were also seen playing thumb pianos and other musical instruments with friends and relatives gathered in a designated place to collectively make music as a way of easing the tension associated with bereavement. The group musical performances held during bereavement often lasted for seven days. The daily performance are held between $9.00 \mathrm{pm}$ to 12.00 midnight daily for six days and on the seventh day it begins at $9.00 \mathrm{pm}$ and continues into the early hours of the day such as $4.30 \mathrm{am}$ or 5.00am. 


\section{Lessons for the Nigerian Music Therapists}

There are very vital issues which the music therapists should know if the application of music in healing is to be efficacious. In Nigeria, being sick is a great burden on both the sick person and his kinsmen because of the physical challenges and the financial burden that it brings. Thus ill health is a threat to man in numerous ways that we can immediately imagine. Hence Aluede (2009) opines:

The eminence of health is captured in texts such as: Health is Wealth, When Health is Lost all is Lost, No Sickness No Suffering, and Death is a small enemy but Sickness is The Great Destroyer. These comments are indicative of the peoples' views of illness and its effect on the society (p.1).

A pertinent question therefore arises:'Is prevention not better than cure?" In Nigeria, song texts whether religious, satirical, didactic, informative or historical play calmative and diversionary roles in music therapy. Today the avenues of these performances are shrinking rapidly as economic pursuits have adversely affected our sense of leisure and consequently we are left with very limited time to listen to or join in the performance of music. Put differently, how much music do we listen to on a daily basis? And what kind of music do we really listen to? Even if the answer to these questions are the affirmative, studies have shown that popular music in Nigeria is tailored towards the genres of popular music in Jamaica, USA, and other foreign lands and our presenters and programmes officers in radio and television stations have greater love and passion for foreign music than indigenous ones. This has made these stations good listening channels for the youths who wear earrings and woven hair in imitation of the life styles of Africans in the Diaspora. Little or no 
recognition is given to the tastes of the grown ups and the elderly. The music that accommodates the interest of these classes of people is derogatorily christened "Old school" and rarely aired in our radio and television stations. This in itself is a critical issue which is a product of cultural imperialism. (Although this issue is not within the purview of this paper, Africans need to re-territorialize their sound-space). This practice is against the ethics of music therapy or even aesthetic enjoyment of music. In a swift response to this attitude, Cole (1988) says:

Why do men take greater pleasure in listening to those who are singing such music as they already know than music which they do not know? Is it because, when they recognize what is being sung, it is more obvious that the singer is as it were achieving his aims, and this is pleasant to contemplate? Or is it because it is less pleasant to learn? And the reason for this is that in the one case there is acquisition of knowledge, in the other the use and recognition of it. Further, that which is familiar is always more pleasant than the unfamiliar (p.10).

From the Benedictine Monastery case study, were we to calculate eight times of twenty minutes chanting, we will arrive at two hours forty minutes of music making in a day. Similarly, a full nine sessions of chanting culminates to 3 hours of music making in a day. From this account, for reduction in chanting sessions 70 out of 90 monks were depressed. This means that about $80 \%$ of the monks became sick.

Today in Nigerian communities, music making which used to be an avenue for the development of group solidarity, contact with reality, relief from self concern, socialization with 
peers and avenue for exercise Aluede and Osakue (2009) is dying away with great rapidity. The highest musical avenues enjoyed today are from the ring tones of our cell phones, caller tunes of our friends, music from our car stereos, radio stations and jingles. These avenues do not necessarily involve our contribution and more importantly we would have lied should we claim that we enjoy between thirty minutes and an hour of musical activity each day. When in traditional Nigerian societies music was made from birth to death, it was not supplied but it was a communal activity and the celebrant was also a performer. This design aided speedy recovery from ill health. Today, traditional musical mores in Nigeria is under serious threat from boys' brigade's brass bands and itinerant Disco Jockey mobile vans that are now often hired to supply music (see the photograph below). Without doubt this avantgarde musical performance though hired to provide music for the people, is by and large for a small spectrum of youngsters who originally were not even the targeted group. These strange musical manifests have even worsened matters as what is alien to the people is being forced on them on a daily basis. And so the indigenous people are left with no avenue for authentic recreational activities. On the need for recreational music as a cohesive force among families and communities, Ogisi (2006), remarks that "... government should formulate policies that encourage healthy living through the cultivation of family recreation of which music is the cheapest, most pleasurable and most valuable" (p.86). 


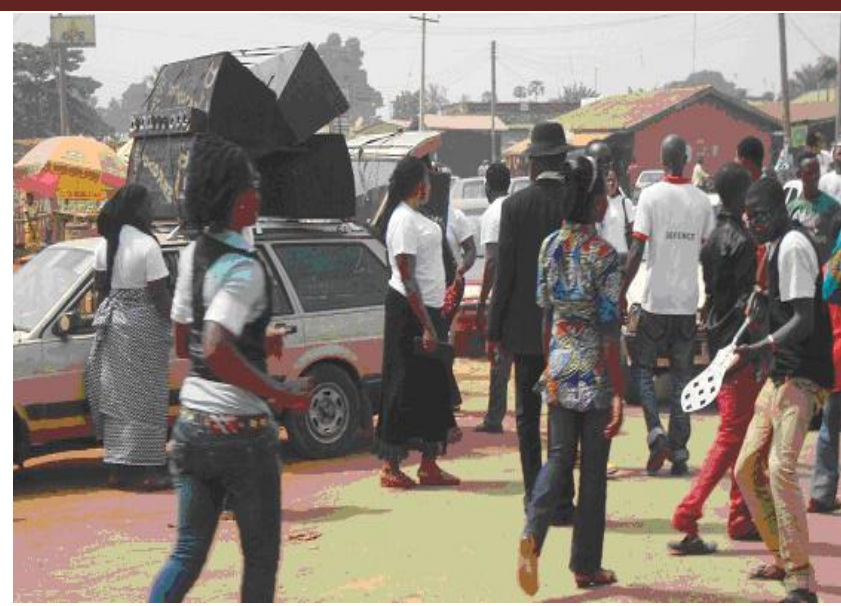

A photograph of a vehicle loaded with power generator, amplifiers and speakers which supplies music for the youths as they go to bury the dead. Needless to ask: Where are our dirges? Where are our indigenous musicians? Can this new entertainment form positively influence the bereaved?

In a similar vein, the churches in Nigeria have not helped matters. Today, the slogan that the youths are the leaders of tomorrow has been abused to a somewhat colloquial if not tautological state. While the youths are constantly being groomed for the future, those outside that age spectrum are left out completely. Those in their late forties to the very old do not have any accommodation in musical activities. They are left out completely in their homes, communities and even the church. For example, a wild and directionless chase of sources for recreational activities in the catholic churches under Uromi Bishopric as a case in point organises monthly youth programmes. This programme entails comedies, talk shows, music and dance performances. Parents and adults are completely out of this arrangement. 


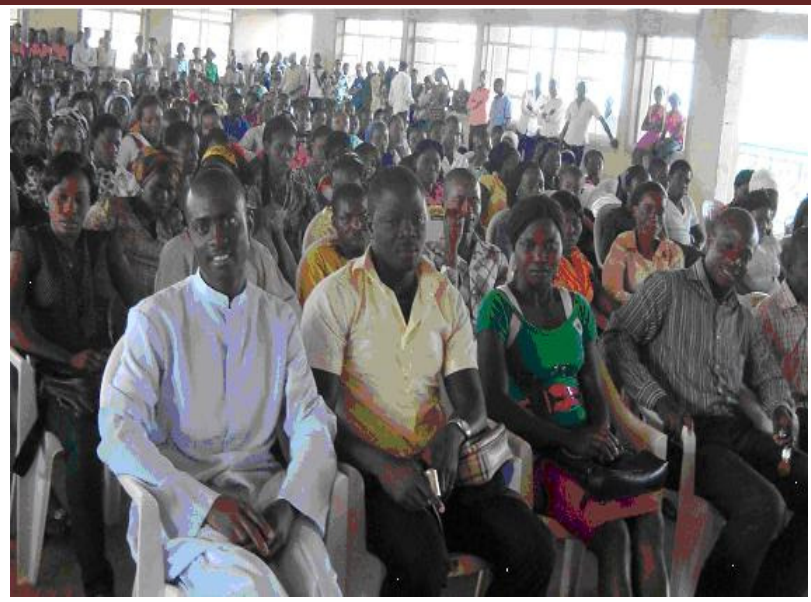

A photograph of Fr. M. Airohubie with the Catholic Youths of Uromi Diocese during the December, 2009 Youth programme.

Aside from the factors identified above, moonlight tales with musical preludes, interludes and postludes, have eclipsed completely. This in itself was a source of chanting, quasi dancing and rigorous arm movements through hand clapping. Every member present therein partook in all the associated activities of story telling. Can we still say that music making in Nigerian communities is communal today? Do we still have songs for birth, death or corrective or lecherous ones? Do we still know of some political and apolitical songs in our communities' repertory? Are our traditional music composers still composing? Why have our traditional songs become archival materials? These missing links may be part of the general unhealthfulness being experienced in present day Nigeria. The music therapist has a lot more to do than it is yet palpable.

\section{Conclusion}

The work force of a nation is not contingent on the sick or the depressed but on the able bodied. It is very clear that music 
healing has been in use ab initio in Nigeria and that it has been kept alive by the carriers of the culture is indicative of its efficacy. However, the need for an enhancement in practice is imperative Aluede and Omoera (2010). Music healing is an age old tradition in Africa in general and Nigeria in particular. However, in recent times little or no attention has been paid to it. If the nation needs a strong but healthy workforce, there should be a systemic appraisal of the use of music in healing and for prophylactic purposes so that a healthy nation will evolve. It is in this light that this paper attempted an examination of the role of music in the maintenance of good health in traditional African society. In trying to establish the relationship between music and good health, inferences were drawn from the Benedictine monks in France which of course forms the theoretical basis of this study. In Nigeria there is a gradual drift from the purposeful use of music for healing to just playing music for music playing sake. The craze for western and other sources of entertainment has created lacunae which need to be filled if music healing traditions are to be of benefit in Nigeria.

Note

i. Edae or Edai is so pronounced and spelt according to the different dialects within Esan.

*Dr. Charles O. Aluede lectures in the Department of Theatre and Media Arts, Ambrose Alli University, Ekpoma. 


\section{References}

Aluede, C.O. (2006) Music Therapy in Traditional Africa societies: Origin, Basis and Application in Nigeria. Journal of Human Ecology 20 (1) 31-35.

Aluede, C.O. \& Omoera, O.S.(2009) The concept of illness and music therapy among members of Iyayi society of the Esan, Edo State of Nigeria. AJPHERD: African Journal for Physical, Health Education, Recreation \& Dance, South Africa. 15. (3). 392 - 408.

Aluede, C. O. (2009) Bibliographical Sources on Music Therapy in Nigeria. Voices: A World Forum for Music Therapy. Retrieved December 9, 2009, from http://www.voices.no/mainissues/mi4000999031.php

Aluede, C.O. \& Osakue, O.S. (2010) Learning From the Past in Organizing Music Therapy Activities for the Geriatric in Esan, Nigeria. Voices. World forum for music therapy, Norway.

Bhaktipada, S. (1988) Joy of No Sex. Moundsville: Palace Publishing.

Cole, B. (1998) Music and Morals. New York: Alba House.

Cottrell A 2000. What is Healing Music? From www.healingmusic.org. (Retrieved on February 23, 2005).

Danielou, A. (1972) The Musical Languages of Black Africa. Africa Music Meeting Organized by UNESCO in Younde, Cameroon 23-27 February, 1970.

Mackinzie, R. (1988) Bands, Boppers and Believers. Harare: Campaign for Leaner Rock.

Mereni, A.E. (1997) Psycholytic Music Therapy in African Traditional Mental Health Care Delivery. A Conference Paper. International Conference on Music and Healing in 
Africa and the Diaspora held between 3-5 Sept. 1997 at the University of Ghana, Legon.

Mereni, A. E (2007) Music Therapy: Concept, scope and competence. Lagos: Apex books limited.

Ogisi, A.A. (2006) Revitalizing Recreational Music Activity in Nigeria. Interlink: Journal of Research in Music.3, 76-87.

Siegel, B.S (1986) Love, Medicine and Miracles. New York : Harper and Row Publishers.

Timothy, K.(1999) Self Healing with Your Voice. www.healingmusic.net/soundhealing. (Retrieved on February 23, 2005). 